\title{
The Structural Investigation of a Sulfated Polysaccharide Produced by a Strain of Marine Pseudomonas
}

\author{
Suda Tandavanitj* and Koichi Okutani* \\ (Received May 26, 1989)
}

\begin{abstract}
The structure of the extracellular, acidic polysaccharide produced by a marine Pseudomonas No. 32 has been investigated. Isolation and purification of the polysaccharide have been accomplished by precipitation from the culture supernatant with Cetavlon and ethanol, followed by DEAE-cellulose ion-exchange chromatography.

The structure of the purified homogeneous preparation has been investigated by methylation analysis, periodate oxidation, Smith degradation and ${ }^{1} \mathrm{H}$ and ${ }^{18} \mathrm{C}$ NMR spectroscopy. Sulfate was determined by ion-chromatography. It was concluded that the polysaccharide is composed of linear disaccharide repeating-units having the following structure:
\end{abstract}

$$
\rightarrow 4)-\alpha \text {-L-Rha } p \text {-(1-3)- } \beta \text {-D-Man } p \text {-(6-O-sulfate })(1 \rightarrow
$$

Sulfated polysaccharides are of broad biochemical interest because of their wide occurrence in animals and plants, typically found in the mucopolysaccharides of mammals and seaweeds, ${ }^{1)}$ and such biological activities as blood anticoagulants and connective tissue stimulants. ${ }^{2)}$ However, only a few papers has reported their presence in microorganisms. ${ }^{3-6}$ ) The present author isolated several strains of polysaccharide-producing bacteria from marine environments such as seawater, ${ }^{7,8)}$ marine sediments, ${ }^{9,10)}$ and marine animals. ${ }^{11}$ Among them, the polysaccharide produced by a Pseudomonas No. 32 strain isolated from seawater showed the presence of ester sulfate as the component.

The purpose of this investigation was to study the isolation, purification and characterization of the sulfated polysaccharide elaborated by a marine Pseudomonas No. 32 strain and to obtain an insight into its structure.

\section{Materials and Methods}

\section{General Methods}

Optical rotations were determined at $25^{\circ} \mathrm{C}$ with a Jasco J-20C automatic recording spectropolarimeter. Ultracentrifugal analyses were performed with a Hitachi 282 analytical ultracentrifuge. Infrared (IR) spectra were recorded on a Jasco A-302 spectrophotometer in $\mathrm{KBr}$ pellets.

Electrophoresis was performed on cellulose acetate strips (Sartorius $11200,57 \times 145 \mathrm{~mm}$ ) in $0.075 \mathrm{M}$ barium acetate buffer $(\mathrm{pH} 7.6)$ for 20 $\min$ at $150 \mathrm{~V}$, and detection with $0.1 \%$ alcian blue in $10 \%$ acetic acid.

The ${ }^{1} \mathrm{H}$ and ${ }^{19} \mathrm{C}$ NMR spectra were recorded on a Jeol FX-90Q NMR spectrometer in $\mathrm{D}_{2} \mathrm{O}$ at $75^{\circ} \mathrm{C}$. Chemical shifts were recorded in ppm relative to sodium 4,4-dimethyl-4-silapentane-1-sulphonate (DSS) added as the internal reference.

Analytical paper chromatography was carried out on Whatman No. 1 paper by the descending method using ethyl acetate-acetic acidformic acid-water (18:3:1:4) as the solvent, and detection with alkaline silver nitrate, aniline hydrogen phthalate, $p$-anisidine, and ninhydrin reagents. Preparative paper chromatography was performed on Whatman $3 \mathrm{MM}$ paper.

Gas-liquid chromatography (GLC) was performed on a Hitachi 263-30 gas chromatography equipped with dual flame ionization detectors. Nitrogen was used as the carrier gas $(30 \mathrm{~m} l)$ $\mathrm{min})$. Other conditions are as follows: glass columns $(0.3 \times 200 \mathrm{~cm})$, (A) $3 \%$ SP-2340 on Uniport HP, (B) $3 \%$ OV-225 on Uniport HP; temperature programmes: $190^{\circ} \mathrm{C}$ for $4 \mathrm{~min}$ then to $250^{\circ} \mathrm{C}$ at $4^{\circ} \mathrm{C} / \mathrm{min}$. GC-Mass spectrometry (GCMS) was performed with a Jeol JMS-DX 300

* Faculty of Agriculture, Kagawa University, Kagawa 761-07, Japan (S. Tandavanitj, 奥谷康一: 香 川大学農学部). 
instrument with an ionization potential of $70 \mathrm{eV}$.

For GLC and GC-MS analyses, monosaccharides were converted into the alditol acetates. Molar ratios were calculated by the appropriate effective carbon response factors. ${ }^{12,18}$

For analyses of component sugars, the polysaccharide was hydrolyzed in a sealed glass tube with $2 \mathrm{M}$ trifluoroacetic acid (TFA) for $12 \mathrm{~h}$ at $100^{\circ} \mathrm{C}$, followed by evaporation to dryness. The products were analyzed by paper chromatography and GLC.

Elemental analyses were performed with a Yanaco MT-3 CHN corder. Uronic acid contents were estimated by the carbazole-sulfuric acid method. ${ }^{14)}$ Protein contents were determined by the method of Lowry et al. ${ }^{15)}$ Amino acids and amino sugars were determined after hydrolysis of the polysaccharide with $4 \mathrm{~N} \mathrm{HCl}$ for $12 \mathrm{~h}$ at $100^{\circ} \mathrm{C}$ by using a Hitachi L-8500 amino acid analyzer. Sulfate content was determined with a Shimazu HIC-6A ion chromatograph by using a Shimpack IC-A1 column $(4.6 \times 100 \mathrm{~mm})$ and a conductivity detector at $40^{\circ} \mathrm{C}$ after hydrolysis with $2 \mathrm{M}$ TFA for $12 \mathrm{~h}$ at $100^{\circ} \mathrm{C}$.

\section{Isolation and Purification of the Polysaccharide}

A bacterial strain of Pseudomonas No. 32 was originally isolated from the surface water of the Seto Inland Sea, Japan. A culture on agar medium was seeded to $10 \mathrm{ml}$ of seawater medium containing sucrose $(3 \%)$, peptone $(0.5 \%)$, and yeast extract $(0.1 \%)$. After incubation for 10 days at $28^{\circ} \mathrm{C}$, the bacterial cells were removed by centrifugation at $70,000 \mathrm{~g}$ for $2 \mathrm{~h}$. To the clear supernatant solution, 2 volumes of ethanol were added. The precipitated polysaccharide was collected by filtration, dissolved in water, re-precipitated with $5 \%$ cetyltrimethylammonium bromide solution (Cetavlon), filtered, dissolved in $4 \mathrm{M} \mathrm{NaCl}$ solution, and precipitated with 2 volumes of ethanol. The collected polysaccharide was dissolved in water, dialyzed against deionized water, and freeze-dried. Average yields of this polysaccharide preparation were $1 \mathrm{~g}$ per $1 l$ of the medium.

The polysaccharide was purified by chromatography on a column $(3.7 \times 25.7 \mathrm{~cm})$ of DEAE-cellulose ion-exchange resin equilibrated with $0.01 \mathrm{M}$ sodium phosphate buffer ( $\mathrm{pH}$ 7.0) and eluted with a stepwise elution of the same buffer containing from 0 to $2 \mathrm{M}$ of sodium chloride. Collected frations were dialyzed, and freeze-dried, respectively, and analyzed for carbohydrates by the phenol-sulfuric acid meth$o d,{ }^{10)}$ indicating that most of the carbohydrate was eluted with $0.9 \mathrm{M} \mathrm{NaCl}$ solution. This polysaccharide preparation was used throughout the present studies.

\section{Chromic Acid Oxidation}

Chromium trioxide oxidation provides a method for identifying the configurations of the glycosidic linkages. ${ }^{17}$ Complete acetylation of the polysaccharide and subsequent chromium trioxide oxidation were conducted according to Dutton and Lim. ${ }^{18)}$

\section{Methylation Analyses}

Methylations were carried out by Hakomori procedure, ${ }^{10)}$ followed by Purdie treatment. ${ }^{20)}$ The products were purified by using Silica$\mathrm{C}_{18}$ cartridge (Sep-Pak cartridge $\mathrm{C}_{1 \mathrm{~B}}$, Waters). ${ }^{21}$ ) Methylated products were hydrolyzed with formic acid (aqueous 90\%) for $1 \mathrm{~h}$ at $100^{\circ} \mathrm{C}$ and then with $2 \mathrm{M}$ TFA for $12 \mathrm{~h}$ at $100^{\circ} \mathrm{C}$, followed by concentration to dryness. Partially methylated sugars were converted to their alditol acetates. The products were analyzed by GLC and GC-MS.

\section{Periodate Oxidation and Smith Degradation}

A solution of the polysaccharide $(50 \mathrm{mg})$ in deionized water $(50 \mathrm{ml})$ was oxidized with 0.02 $M$ sodium metaperiodate $(50 \mathrm{ml})$ for 3 days at $5^{\circ} \mathrm{C}$ in the dark. After the excess periodate was decomposed with ethylene glycol $(12.5 \mathrm{ml})$, the oxidized polymer was reduced with sodium borohydride $(250 \mathrm{mg})$. After dialysis, the product was freeze-dried.

Smith hydrolysis of the periodate oxidized and reduced polymer was effected with $0.5 \mathrm{M}$ TFA for $12 \mathrm{~h}$ at $25^{\circ} \mathrm{C}$ and the degradation products were analyzed for sugar components.

\section{Results and Discussion}

An extracellular sulfated polysaccharide was isolated from the culture supernatant of a marine Pseudomonas No. 32 by precipitation with ethanol and Cetavlon. This material is strongly adsorbed on DEAE-cellulose ion-exchange resin and requires $0.9 \mathrm{M} \mathrm{NaCl}$ solution at $\mathrm{pH} 7$ for elution, providing the evidence for the anionic nature of the polymer. As no uronic acids were detected in this polysac- 


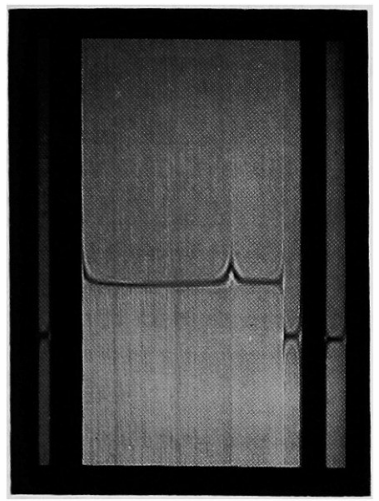

Fig. 1. The sedimentation pattern of the purified polysaccharide. Measurement was done in $0.1 \mathrm{M} \mathrm{NaCl}$ solution $(2.5 \mathrm{mg} / \mathrm{ml})$ at $25^{\circ} \mathrm{C}$. The photograph was taken at $90 \mathrm{~min}$ after the maximum speed $(60,000 \mathrm{rpm})$ was obtained. Direction of sedimentation was from right to left.

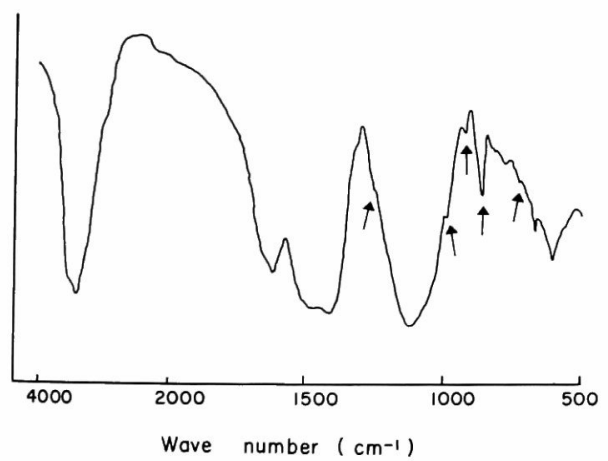

Fig. 2. IR spectrum of the polysaccharide. Arrows indicate the presence of sulfates.

charide, the possibility of bound sulfate rendering these polysaccharides acidic was the basis for the present studies. The purified polysaccharide preparation obtained by DEAEcellulose ion-exchange column was found to be homogeneous by both ultracentrifugal (Fig. 1) and electrophoretic analyses. The approximate sedimentation coefficient was calculated to be $2.48 \mathrm{~S}$, and the polysaccharide had $[\alpha]_{\mathrm{D}}-9.1^{\circ}$ (c 0.3 , water), which did not coinside with the value of $-70.5^{\circ}$ calculated by using Hudson's rules of isorotation. ${ }^{22}$ ) The ash content of the polysaccharide is unusually high, presumably owing to the high content of sulfated ash (Anal. Found: $\mathrm{C}, 21.18 ; \mathrm{H}, 2.83 ; \mathrm{N}, 3.47 ; \mathrm{SO}_{4}$, 16.26\%; ash, 27.10\%).

As shown in Fig. 2, the IR spectrum of the
Table 1. Sugar analyses on the original and modified polysaccharide

\begin{tabular}{|c|c|c|c|c|}
\hline \multirow{2}{*}{$\begin{array}{l}\text { Starting } \\
\text { materials }\end{array}$} & \multicolumn{4}{|c|}{ Molar ratios } \\
\hline & Rha & Man & $\begin{array}{l}\text { 1-deoxy- } \\
\text { erythritol }\end{array}$ & Sulfate \\
\hline $\begin{array}{l}\text { Original } \\
\text { polysaccharide }\end{array}$ & 1 & 1 & - & 1 \\
\hline $\begin{array}{l}\text { Periodate } \\
\text { oxidized }\end{array}$ & - & 1 & 1 & 1 \\
\hline $\begin{array}{l}\text { Partially } \\
\text { desulfated* }\end{array}$ & 1 & 1 & 一 & 0.3 \\
\hline $\begin{array}{l}\text { * Prepared by tre } \\
\text { methanol for } 1 \\
\text { and freeze-dryin } \\
\text {-: Not detected. }\end{array}$ & $\begin{array}{l}\text { ating } t \\
h \text { at ro } \\
\text { g. }\end{array}$ & $\begin{array}{l}\text { polys } \\
\text { n temp }\end{array}$ & $\begin{array}{l}\text { accharide with } \\
\text { perature, follov }\end{array}$ & $\begin{array}{l}3 \% \mathrm{HCl} \text { in } \\
\mathrm{d} \text { by dialysis }\end{array}$ \\
\hline
\end{tabular}

Table 2. Oxidation of the polysaccharide by chromium trioxide

\begin{tabular}{lccrr}
\hline \hline Reaction time (h) & & 0 & 12 & \multicolumn{1}{c}{24} \\
\hline Sugar analysis* & Rha & 100 & 33.4 & 22.0 \\
& Man & 100 & 2.4 & 1.8 \\
\hline$*^{*}$ Percent in the molar proportions. & &
\end{tabular}

polysaccharide showed absorption bands at $1250,990,930,860$ and $730 \mathrm{~cm}^{-1}$ indicating the presence of sulfate ester..$^{5,23-25)}$ The amino sugar, amino acid, and protein were not detected in this polysaccharide.

\section{Sugar Analyses}

Hydrolysis of the polysaccharide with $2 \mathrm{M}$ TFA gave two monosaccharides. Paper chromatography and GLC evidenced that rhamnose (Rha) and mannose (Man) were contained in the molar ratio $1: 1$ (Table 1 ). Rhamnose was confirmed to be the L-configuration, and mannose to be the $\mathrm{D}$-configuration by polarimetric analyses after isolation by preparative paper chromatography.

\section{Chromic Acid Oxidation}

Chromium trioxide oxidation provides a method for identifying the anomeric configurations. The kinetics of the degradation of each sugar were monitored by GLC analyses after hydrolysis of the products (Table 2) and showed that the mannose residue was immediately degraded and was thus in the $\beta$ configuration. With rhamnose, the rate of oxidation resulted in incomplete. It is known that the rate of oxidation of the $\alpha$ and $\beta$ anomers of the rhamnosyl residues does not exhibit sufficient difference to be conclusive. ${ }^{20)}$ 
Table 3. Assignments of ${ }^{18} \mathrm{C}$ NMR signals of the polysaccharide

\begin{tabular}{crlllll}
\hline \hline \multirow{2}{*}{ Sugar residues } & \multicolumn{7}{c}{ Chemical shifts (ppm) } \\
& \multicolumn{1}{c}{ C-1 } & C-2 & C-3 & C-4 & C-5 & C-6 \\
\hline Rha & $103.4(167.2)$ & 73.6 & 70.5 & 80.0 & 67.9 & 19.5 \\
Man & $99.3(164.8)$ & 73.1 & 83.1 & 69.7 & 76.9 & 70.5 \\
\hline
\end{tabular}

Values of coupling constants $\left({ }^{1} \mathrm{~J}_{0-1}, \mathrm{H}-\mathrm{I}\right)$ are given in $\mathrm{Hz}$ in parentheses.

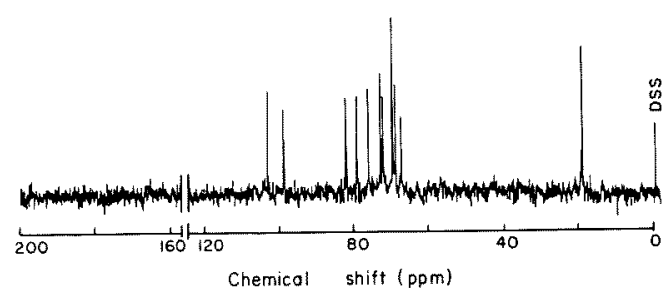

Fig. 3. ${ }^{13} \mathrm{C}$ NMR spectrum of the polysaccharide in $\mathrm{D}_{2} \mathrm{O}(50 \mathrm{mg} / \mathrm{ml})$.

\section{${ }^{1} \mathrm{H}$ and ${ }^{13} \mathrm{C} N M R$ Spectroscopy}

The ${ }^{1} \mathrm{H}$ and ${ }^{13} \mathrm{C}$ NMR signals were assigned by comparison with literature values of related structures. ${ }^{27-29)}$ The carbohydrate analysis as described above, was in agreement with the ${ }^{13} \mathrm{C}$ NMR spectra (Fig. 3 and Table 3) which showed two anomeric carbons at $\delta 103.4$ and $99.3 \mathrm{ppm}$. Similary, two anomeric protons ( $\delta 4.97$ and $4.86 \mathrm{ppm}$ ) were present in the ${ }^{1} \mathrm{H}$ NMR spectrum, although ${ }^{1} \mathrm{H}$ NMR spectra were poorly resolved. The presence of a rhamnosyl residue was indicated by the ${ }^{15} \mathrm{C}$ signal at $\delta 19.5 \mathrm{ppm}$ assignable to the 6-methyl carbon. The INEPT spectrum showed that a signal at $\delta 70.5 \mathrm{ppm}$ was a methylene carbon, indicating the C-6 substituted mannosyl residue. In the ${ }^{13} \mathrm{C}$ NMR spectrum, carbon atoms of the linkage position were also observed at $\delta 83.1$ and $80.0 \mathrm{ppm}$. No ${ }^{1} \mathrm{H}$ and ${ }^{13} \mathrm{C}$ signals corresponding to acyl and carboxyethylidene substituents were observed. ${ }^{30,313}$

The coupling constant values $\left({ }^{1} J_{C, H 1}\right)$ for the anomeric carbons (Table 3 ) showed two sugar residues to be involved in $\alpha$ and $\beta$ linkages, respectively. Although further evidence was necessary to confirm the anomeric determination of the rhamnosyl residue, the present results and the fact that naturally occurring Lrhamnosyl residues in the polysaccharide generally have the $\alpha$ configurations ${ }^{32}$ ) allow the tentative assignment as shown in the conclusion.

\section{Methylation Analyses}

The IR spectrum of the methylated polysac-
Table 4. Methylation analyses of the polysaccharide

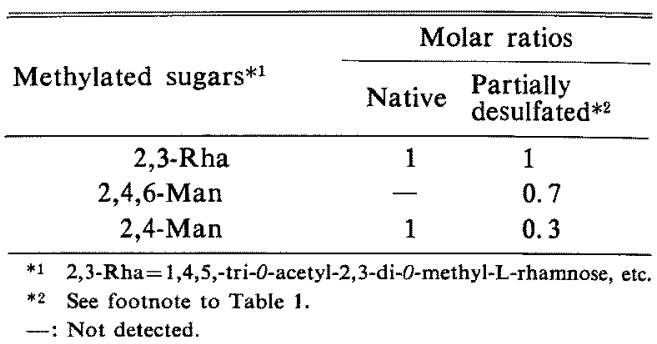

charide showed strong absorption in the carbonyl region but no absorption in the hydroxyl region. Methylation analyses gave the results shown in Table 4. The results showed that this polysaccharide contained $(1 \rightarrow 4)$ linked rhamnosyl and $(1 \rightarrow 3,6)$ linked mannosyl residues in the molar ratio $1: 1$. The appearance of 2,4,6-tri-O-methylmannose in the products from partially desulfated polysaccharide shows that sulfates were linked to mannosyl residues at position C-6.

Methylation analyses showed that both sugar residues are in the pyranose forms.

\section{Periodate Oxidation}

All of the rhamnose residues were destroyed on periodate oxidation of the polysaccharide, whereas the mannose residues were resistant (Table 1). Sugar analyses after periodate oxidation of the polysaccharide yielded the expected $1: 1$ ratio of 1-deoxyerythritol and mannose. After Smith degradation, no polymeric material was obtained. These data support the structure given by the methylation analyses.

In conclusion, from the combined evidence provided by chemical analyses and NMR studies, it may be suggested that this polysaccharide is composed of disaccharide repeating-units having the following structure:

$$
\begin{array}{r}
\rightarrow 4) \text { - } \alpha \text {-L-R hap-(1-3)- } \beta \text {-D-Man } p(1 \rightarrow \\
\uparrow 6 \\
\text { Sulfate }
\end{array}
$$




\section{Acknowledgments}

We thank Dr. T. Koyama of Snow Brand Research Institute of Life Science, for the NMR measurements. We are also grateful to Dr. H. Tamura and K. Matsubara of Kagawa University for measurements of the GC-MS and for his technical assistance, respectively.

\section{References}

1) N. Seno: in "Structure and Functions of Mucopolysaccharides" (ed. by E. Hasegawa et al.), Nankodo, Tokyo, 1968, pp. 7-24.

2) R. L. Whistler, A. H. King, G. Ruffini, and F. A. Lucas: Arch. Biochem. Biophys., 121, 358363 (1967).

3) G. K. Darby, A. S. Jones, A. S. Kennedy, and R. T. Walker: J. Bacteriol., 103, 159-165 (1970).

4) M. Koncewicz: Biochem. J., 130, 40-41 (1972).

5) J. Steber and K. H. Scheifer: Arch. Microbiol., 105, 173-177 (1975).

6) K. Inoue, H. Korenaga, and S. Kadoya: $J$. Biochem., 92, 1775-1784 (1982).

7) K. Okutani: Nippon Suisan Gakkaishi, 48, 16211625 (1982).

8) K. Okutani: Nippon Suisan Gakkaishi, 50, 10351037 (1984).

9) K. Okutani: Tech. Bull. Fac. Agr. Kagawa Univ., 36, 47-51 (1984).

10) K. Okutani: Nippon Suisan Gakkaishi, 51, 493496 (1985).

11) K. Okutani: Tech. Bull. Fac. Agr. Kagawa Univ., 36, 135-140 (1985).

12) D. P. Sweet, R. H. Shapiro, and P. Albersheim: Carbohydr. Res., 40, 217-225 (1975).

13) J. K. Baird, M. J. Holroyde, and D. C. Ellwood: Carbohydr. Res., 27, 464-467 (1973).

14) Z. Dische: J. Biol. Chem., 167, 180-198 (1947).

15) O. H. Lowry, N. J. Rosebrough, A. L. Farr, and R. J. Randall: J. Biol. Chem., 193, 265275 (1951).

16) M. Dubois, K. A. Gilles, J. K. Hamilton, P. A. Rebers, and F. Smith: Anal. Chem., 28, 350356 (1956).

17) S. J. Angyal and K. James: Aust. J. Chem., 23, 1209-1221 (1970).

18) G. G. S. Dutton and A. V. S. Lim: Carbohydr. Res., 144, 263-276 (1985).

19) S. Hakomori; J. Biochem., 55, 205-207 (1964).

20) T. Purdie and J. C. Irvine: J. Chem. Soc., 83, 1021-1037 (1903).

21) R. Ahrens, B. Jann, K. Jann, and H. Brade: Carbohydr. Res., 179, 223-231 (1988).

22) C. S. Hudson: J. Am. Chem. Soc., 31, 66-86 (1909).

23) I. Ishizuka, M. Suzuki, and T. Yamakawa: $J$. Biochem., 73, 77-87 (1973).

24) T. Yamakawa, N. Kiso, S. Handa, A. Makita, and S. Yokoyama: J. Biochem., 52, 226-227 (1962).

25) K. A. Karlson, B. E. Samuelsson, and G. O. Steen: Biochim. Biophys. Acta., 337, 356-376 (1974).

26) M. Beurret, M. Vignon, and J. P. Joselleau: Carbohydr. Res., 157, 13-25 (1986).

27) P. E. Jansson, L. Kenne, and T. Wehler: Carbohydr. Res., 179, 359-368 (1988).

28) J. P. Joseleau and M. F. Marais: Carbohydr. Res., 179, 321-326 (1988).

29) R. R. Contreras, J. P. Kamerling, J. Breg, and J. F. G. Vliegenthart: Carbohydr. Res., 179, 411-418 (1988).

30) Y. A. Knirel, V. V. Dashunin, A. S. Shashkov, N. K. Kochetkov, B. A. Dmitriev, and I. L. Hofman: Carbohydr. Res., 179, 51-60 (1988).

31) P. J. Garegg, P. E. Jansson, B. Lindberg, F. Lindh, J. Lonngren, I. Kvarnstrom, and W. Nimich: Carbohydr. Res., 78, 127-132 (1980).

32) J. Hoffman, B. Lindberg, and S. Svensson: Acta. Chem. Scand., 26, 661-666 (1972). 